\title{
COMPARATIVE COST/BENEFIT OF ALTERNATIVE/CONVENTIONAL FEEDSTUFF IN BROILER PRODUCTION IN NIGERIA.
}

\author{
${ }^{1}$ BOLU, S.A. and IBIKUNLE, $M$ \\ Dept. of Animal Production, University of Ilorin \\ Ilorin, Nigeria. \\ bolusao2002@yahoo.co.uk
}

\begin{abstract}
An experiment was conducted using broilers to determine the relative cost /benefit of the use of conventional (corn/soya bean based) and alternative (less of corn and soya bean substituted with agro-allied and industrial by-products) feedstuffs. Completely randomized design was used and the experiment conducted for a period of eight (8) weeks. Feed intake and weight gain were different for the various dietary treatments $(P<0.05)$. Birds fed diet containing maize/soyabean had significantly medium fed intake but relatively higher $(P<0.05)$ weight gain

(411.88 $\mathrm{gb}^{-1} \mathrm{wk}^{-1}$ and $180 \mathrm{~g} \mathrm{~b}^{-1} \mathrm{wk}^{-1}$ respectively). Corn/soya bean based diet was relatively more acceptable than the alternative feedstuff included diets. Feed /gain ratio and cost/benefit ratio were significantly affected by the use of conventional or alternative feedstuff in the diet of broilers $(P<0.05)$. However, birds fed maize/soyabean-based diet had better values for these parameters (2.88 and 79.10 for feed/gain and cost/benefit ratio respectively). Birds fed corn/soya bean based diets required less kilogram offeed to gain a kilogram of weight. Nutrient retention was different $(P<0.05)$ for all the dietary treatments. Birds tended to retain more nutrients when fed maize soya bean based diet. The protein and fat retentions observed for birds fed corn/soya bean based diets were, respectively, 94.3 and 79.2\%. Marginal cost added per additional kilogram of feed produced was significantly affected $(P<0.05)$ by the use of the various categories of feedstuff. Generally, as the use of corn /soya bean reduced in the diets, marginal cost of feed production tended to decrease. As much as $\$ 10$ was reduced from the cost of producing an extra kilogram of feed using alternative feedstuff to produce broiler diets vi-a-viz when corn/soya bean was used. The use of alternative feedstuff reduced the cost/kg offeed to $\$ 24.17$ compared to atleast $\$ 34$ per kilogram of corn/soya bean based diet produced. In the same vein, the marginal revenue accruable to broiler production using alternative feedstuff was significantly higher $(P<0.05)$ than for broilers produced using corn/soyabean based diets. Atleast, $N 17$ additional revenue was realized for every kilogram of broiler meat produced using alternative feed stuffs.
\end{abstract}

keywords: Broilers, alternative feedstuffs 


\section{INTRODUCTION}

Research concerns in the livestock industry over the last decade in Nigeria have focused on the discovery of novel foodstuffs. This feat has also made "least cost ration" a common terminology to nutritionists. During the period in focus, myriads of alternative feedstuffs (e.g. wheat offal) were used in livestock diets to substitute conventional ones (e.g. maize, soybean). Several of these research attempts suggested that novel feedstuffs could replace the conventional ones (Aduku, 1992, Atteh and Adedoyin, 1993, Bolu and Balogun 1998).

Once novel feedstuffs became adapted to livestock feeds, the cost also begins to rise in response to demand (Aduku, 1992). The consequent rise in price of these alternative feedstuffs may not justify their relative use as animal feed ingredients, especially during the harvest seasons of the conventional feedstuffs (Fetuga, 1977). In Ilorin (Nigeria) locality, the relative cost of alternative feedstuffs hardly changes due to season or other factors. However, the cost of maize in the last five years within this same locality had oscillated between $\$ 8 \mathrm{~kg}^{-1}$ during harvest to $\$ 55 \mathrm{~kg}^{-1}$ during the off-season (Bolu and Balogun, 1998, 2000). The advantage of these varied seasonal prices is that livestock farmers can take advantage of the on-season to incorporate maize in livestock feeds at about $60 \%$ and take advantage of efficient feed conversion and profitable cost/benefit ratio. On the other hand, with adequate storage facilities, farmers could take advantage of the on-season, to maintain relatively constant profit margin all through the year, instead of using non-convectional feedstuff with their attendant poor nutrient utilization efficiency (Fetuga, 1977, Babatunde and Fetuga, 1980).

The current study incorporated maize and soyabean as animal feed ingredients during the on-season at a high ratio in broilers diet and compared their performance and cost/benefit ratio to those of birds fed on rations that contained mostly non-conventional feedstuffs as substitutes.

\section{Study area}

\section{MATERIALS AND METHODS}

Data used for the present study was obtained from experiments conducted using exotic chicken purchased in the Departmental Research pavilion of the university, in Ilorin, middlebelt of Nigeria. The research unit is located on latitude $08^{\circ} 32^{\prime} \mathrm{N}$ and longitude $04^{\circ} 34^{\prime} \mathrm{E}$. The mean annual temperature is $32^{\circ} \mathrm{C}$.

\section{Experimental Condition}

One hundred (120) shaver-stars cross day old broiler of mixed were used in this experiment. The birds were housed in electrically heated battery cages. Birds were fed commercial feeds (Animal Care Broiler Starter $\mathrm{CP}=24.2 \%$ analyzed) for two weeks into the experiment to acclimatize them to experimental conditions. At the end of two weeks, 
birds were weighed and randomly allocated to dietary treatments (Table 1 ). Diet 1 was formulated with only conventional feedstuffs (maize, soyabean, etc) while diets 2 and 3 were formulated by substituting for maize and soyabean, with non-conventional agroallied by-product feedstuffs. All feed were iso-nitrogenous and iso-caloric. Birds were replicated in four (4) pens of ten (10) birds pen.

\section{Data Collection}

Feed and water were given ad libitum. Weekly records of feed intake (feed offered feed rejected) and weight gain (final weight initial weight) were taken.

Feed :gain ratio was also computed from these results as:

$$
\begin{aligned}
& \text { Feed consumed }(g) \\
& \text { weight gain }(g)
\end{aligned}
$$

The experimental period was eight (8) weeks. At the end of the experiment, blood samples were taken from the wing vein of each group into a collecting tube containing ethylene diamine tetra acetate (EDTA). Haematological assay was carried out as described by Dacie and Lewis (1977) to determine Packed Cell Volume (PCV), Haemoglobin concentration (Hb), total Red Blood Cell (RBC) count, total White Blood Cell (WBC) count and differential WBC count (ie lymphocytes, neutrophil, monocytes, basophils and eosinophils). Blood clotting time was determined using glass slide method described by Orji et al, 1986. Nutrient retention trials were conducted during week four (4) of the experiment. A weighed amount of feed was fed and the feaces voided was dried and weighed. The nutrient content of both feed and feaces was analyzed and nutrient retention computed as:

$$
\frac{\text { Nutrient voided infeaces }(g)}{\text { Nutrient consumed }(g)} \times 100
$$

Proximate analysis of the feed and feacal samples was conducted according to the method described by AOAC, (1984). At the end of the experiment, four (4) birds were selected from each group for carcass evaluation. They were starved for 10 hours, weighed, slaughtered by head decapitation, dressed and cut into primal parts. Relative fresh organ weights and primal cuts were recorded.

Data collected were subjected to analysis of variance (ANOVA) using the model for completely randomized design (Steel and Torrie, 1980). Differences between treatment means was determined by Duncan Multiple Range Test Duncan (1955).

\section{RESULTS}

Feed intake and weight gain observed were significantly different $(\mathrm{P}<0.05)$ for the dietary treatment (Table 2). Birds fed the diet containing conventional maize and soyabean recorded highest feed intake and weight gain $\left(411.88 \mathrm{~g} \mathrm{~b}^{-1} \mathrm{wk}^{-1}\right.$ and $180 \mathrm{~g} \mathrm{~b}^{-1} \mathrm{wk}^{-1}$ respectively). Corn/soya bean based diet was relatively more acceptable. Feed/gain ratio and cost/benefit ratio were significantly affected $(\mathrm{P}<0.05)$ by the dietary conditions. 
Broilers fed corn/soya based diets had better feed/gain and cost of producing a kilogram of broiler meat than birds fed the other diets. Results observed for these birds (on conventional feedstuff) for feed/gain and cost/benefit ratio were 2.28 and $\$ 79.10$ respectively. Mortality observed in this study were not different $(\mathrm{P}>0.05)$ (Table 2$)$ for all the diets. Nutrient retentions recorded in this study were significantly different $(\mathrm{P}<0.05)$ (Table 2$)$ for all the diets. Birds fed diets containing the (maize/soyabean) conventional feedstuff tended to have higher retentions for both protein and fat $(79.20$ and $94.3 \%$ respectively) than did birds fed alternative feedstuff based diets. Haematological indices observed (Table 3$)$ did not differ $(\mathrm{P}>0.05)$ for all the diets fed. However, for most of parameter observed, birds fed on the convectional (maize/soyabean) diet exhibited superior haematological competence. Carcass evaluation of the birds fed the different diets did not differ $(\mathrm{P}>0.05)$ (Table 4). The relative percentage of the primal cuts and organs were not different for all the diets.

\section{DISCUSSION}

Birds have been known to eat toward satisfying their energy requirement (NRC, 1994). The fibrous nature of non-convectional feed stuff, tends to dilute the energy concentration and reduce nutrient availability in the diet (Bolu and Balogun, 1998). Since all the diets were both iso-nitrogenous and iso-caloric, the response to the treatments was a clue to the quality of the nutrients fed. Maize and soya bean has been considered as standards to other plant energy and protein sources (Yen and Baker, 1977). Study with cockerels showed that maize fed at $64 \%$ inclusion level gave better result than did other concentrates (Sonaiya, 1986). Broilers fed the diet containing maize-soya bean recorded a highest feed intake, which was translated to weight gain more efficiently than broilers fed the other diets. Birds fed on other diets in this study actually consumed more than was efficiently utilized. This may be due to the fibrous nature of the diets. Fibrous feedstuffs have been reported to reduce nutrient utilization (Aduku, 1992). It can also be observed that although the cost $/ \mathrm{kg}$ feed of maize-soyabean based diet was higher than for other diets, it was more profitable and beneficial to feed this diet than the other diets (i.e. $\$ 79.10$ was spent on feed for the birds to gain $1 \mathrm{~kg}$ ). It also implies that the cost of producing a kilogram live-weight was $25 \%$ cheaper when maizesoya bean was used. This observation was also supported by the relative feed/gain ratios. Birds fed maize soya bean combination required $2.28 \mathrm{~kg}$ feed to gain $1 \mathrm{~kg}$ liveweight compared to $3.21 \mathrm{~kg}$ required for other diets. This observation was supported by NRC, (1994) that maize and soya bean ensures efficient feed utilization. It is pertinent also to note that birds fed maize-soybean based diet recorded the lowest mortality. It has been reported that good nutrition (especially interms of availability of the nutrients) is germane to the health and well being of livestocks (Bolu and Balogun, 1998). The fat and protein retention values observed in this study aligned with and tended to buttress the facts stated above. The birds fed the diet that had maize-soybean retained more fat and protein. This was translated to the weight gain and development of body 
weight. It has been noted that retention of nutrient for maize among concentration is higher and also for soya bean relative to other plant proteins (Sonaiya, 1986, Babatunde and Fetuga, 1980). Nutrient retained by the birds fed other diets was not comparable possibly due to the fibrous nature of the diets and balance of amino acid (Chung and Baker, 1990). Using the above mentioned indices (feed intake, weight gain, feed:gain, nutrient retention and economic parameters) as yardsticks, it can be observed that maizesoya bean based diet resulted in higher production responses of broiler than alternative feedstuff.

Prices of most conventional feedstuff respond to economic and seasonal factors. Their comparative utility to the alternative non-conventional feedstuffs however, cannot be over-emphasized. The use of primary feedstuff other than their by-product has been encouraged (Fetuga,1977).

\section{CONCLUSION}

From this present study the cost implication in a broiler farm favours the use of conventional feedstuffs rather than their alternatives. It can also be seen that the use of primary feedstuffs resulted in efficient production than alternative derivative. The use of maize-soyabean based diet is preferable in broiler production. Farmers can be encouraged to ensure storage of these feedstuffs in their on-seasons for the purpose of ensuring all-round-the-year availability. This will relatively stabilize the overall profit and cost implication, throughout the year. Government can also help in terms of capacity building for improved grain production and storage. This can be released to genuine farmers at prices comparable to on-season cost. If, and when these logistics are in place the use of non-conventional feedstuffs can be channeled to other sectors that are noncommercial livestock concerns e.g. subsistence livestock production. Government could also provide micro-credit facilities to genuine farmer to purchase these feedstuffs from

Table 1Composition of Experimental diet (\%)

\begin{tabular}{llll}
\hline Ingredients & $\mathbf{1}$ & Diets \\
& 60 & $\mathbf{2}$ & $\mathbf{3}$ \\
\hline Maize $^{\mathrm{xx}}$ & 30 & 30 & 30 \\
Soya bean $^{\mathrm{xx}}$ & 5.6 & - & 20 \\
Fishmeal $^{\mathrm{xx}}$ & - & 20 & - \\
Wheat offal* $^{*}$ & - & 25.6 & - \\
Brewers dried grain $_{\text {Corn offal* }}^{*}$ & - & - & - \\
PKC $^{*}$ & - & - & 20 \\
Blood meal $^{*}$ & - & - & 10.6 \\
Basal $^{+\mathrm{o}}$ & 4.4 & 4.4 & 10 \\
Total & $\mathbf{1 0 0 . 0 0}$ & $\mathbf{1 0 0 . 0 0}$ & $\mathbf{1 0 0 . 0 0}$
\end{tabular}


Analyzed nutrient content

$\begin{array}{llcl}\text { C.P }(\%) & 24.60 & 24.69 & 25.01 \\ \text { Crude fibre }(\%) & 3.4 & 5.27 & 4.82 \\ \text { Ether Extract }(\%) & 3.6 & 4.4 & 4.6 \\ \text { Energy (Kcal/kg) } & 2975 & 2969 & 2968\end{array}$

+ Contained: vitamin/mineral premix, 0.25; salt, 0.35; oyster shell, 1.10; bone meal,

2.50; lysine, 0.10 and methionine, 0.10

** Conventional feedstuffs

* Non conventional feedstuffs

○. Vitamin/mineral premix supplied/kg of diet:-

vitamin $A ., 80.000$ i.u,; vit $\mathrm{D}_{3}, 1,200$ i.c.u.., vitE 31 i.u, vit $\mathrm{B}_{1} 2 \mathrm{mg}$, vit $\mathrm{B}_{2} 3 \mathrm{mg}$

niacin $10 \mathrm{mg}$, pantothenate $150 \mathrm{mg}$, manganese $80 \mathrm{mg}$, zinc $50 \mathrm{mg}$, copper $2 \mathrm{mg}$, Iodine

$1.2 \mathrm{mg}$, cobalt $0.2 \mathrm{mg}$, selenium $0.1 \mathrm{mg}$.

Table 2.Effect of Dietary Treatment on the Performance of Broilers

\begin{tabular}{llrr}
\hline Item & \multicolumn{3}{c}{ Diets } \\
& $\mathbf{1}$ & $\mathbf{2}$ & \multicolumn{1}{c}{$\mathbf{3}$} \\
\hline Feed intake $\left(\mathrm{g} \mathrm{b}^{-1} \mathrm{wk}^{-1}\right)$ & $411.88^{\mathrm{a}}$ & $408.37^{\mathrm{b}}$ & $410.89^{\mathrm{b}}$ \\
Weight gain $\left(\mathrm{g} \mathrm{b}^{-1} \mathrm{wk}^{-1}\right)$ & $180.0^{\mathrm{a}}$ & $119.05^{\mathrm{b}}$ & $122.15^{\mathrm{b}}$ \\
Feed/gain & $2.28^{\mathrm{a}}$ & $3.43^{\mathrm{b}}$ & $3.21^{\mathrm{b}}$ \\
Cost/kg feed (N) & & & \\
\hline
\end{tabular}

* $\quad$ Cost of feed incurred for every $1 \mathrm{~kg}$ weight gain (marginal cost)

** Marginal revenue for every $1 \mathrm{~kg}$ broiler meat.

a,b,c : Mean within row with different superscript are different $(\mathrm{P}<0.05)$

TABLE 3Effect of dietary treatments on the Haematology of broilers

\begin{tabular}{llll}
\hline Item & \multicolumn{3}{c}{ Diets } \\
\hline Haemoglobin (gm\%) & 1 & 2 & 3 \\
Pcv (\%) & 12 & 10 & 10 \\
RBC (x10 12 /) & 28 & 27 & 27 \\
WBC (x 10/1) & 212 & 215 & 211 \\
Lymphocytes (\%) & 3.2 & 3.1 & 3.0 \\
Neutrophil (\%) & 64 & 65 & 67 \\
Monocytes (\%) & 43 & 42 & 42 \\
Basophil (\%) & 3 & 1 & 2 \\
Eosinophil (\%) & - & - & - \\
Clotting time (min.) & - & 2 & - \\
\hline
\end{tabular}


Table 4: Effect of dietary treatments on the actual and relative weights (g/100g body weight) of fresh organ and primal cuts of Broilers

\begin{tabular}{lccrrrr}
\hline Item & \multicolumn{6}{c}{ Diets } \\
& \multicolumn{1}{c}{$\mathbf{2}$} & \multicolumn{2}{c}{} & $\mathbf{3}$ \\
\hline Live weight (g) & $\begin{array}{l}\text { Actual } \\
1440\end{array}$ & Relative & $\begin{array}{c}\text { Actual } \\
952.40\end{array}$ & Relative & $\begin{array}{l}\text { Actual } \\
897.20\end{array}$ & Relative \\
Dressing & & & & & & \\
percentage (\%) & 1074 & 74.59 & 733.61 & 76.45 & 684.65 & 76.31 \\
& & & & & & \\
Wings & 124.41 & 8.64 & 84.28 & 8.85 & 77.79 & 8.67 \\
Thigh & 154.66 & 10.74 & 104.48 & 10.97 & 96.45 & 10.75 \\
Drumstick & 163.87 & 11.38 & 110.95 & 11.65 & 103.27 & 11.51 \\
Keel & 164.73 & 11.44 & 108.67 & 11.41 & 103.18 & 11.50 \\
Back & 203.04 & 14.10 & 135.24 & 14.20 & 126.51 & 14.10 \\
Gizzard & 45.16 & 3.56 & 35.72 & 3.75 & 32.75 & 3.65 \\
Liver & 31.97 & 2.22 & 22.76 & 2.39 & 20.55 & 2.29 \\
Heart & 7.20 & 0.50 & 4.76 & 0.50 & 4.67 & 0.52 \\
\hline
\end{tabular}

\section{REFERENCES}

Aduku, O.A. (1992). Practical livestock feed production in the Tropics. Asekome and Co. Publishers. Zaria. Ed 1.: 1- 30.

AOAC (1984). Official Method of Analysis. Association Official Analytical Chemists Washington, DC. Ed. 14: 105 -280

Atteh, J. O. and Adeyoyin, O. D. (1993). Effects of replacing dietary fishmeal with Maggot meal on the Performance and nutrient retention of laying hens. Nig. J. Anim. Prod:20:50 55.

Babatunde, G. M. and Fetuga, B. L. (1980). Contribution made by research to poultry production and the green revolution; Nigeria: Green Rev.Publication. 2: 15-25.

Bolu, S. A. and Balogun, O. O. (1998). Comparative energy value of sorghum distiller's waste, maize cob and shea butter cake for pigs. Nig. J. of Anim. Prod.:; 25: 157162 
Bolu, S. A. and Balogun, O. O. (1998). Performance of Laying hens fed graded levels of locally produced and natural vitamin premix. Nig. J. of Anim. Prod. $26: 54-59$

Bolu, S. A. and Balogun, O. O. (2000). Comparative performance and carcass evaluation of broilers fed locally produced natural vitamin premix and two (2) commercial vitamin/mineral premixes. Nig. J. of Pure and Applied Sci.:5:1110 1113

Chung, T. K. and Baker, D. H. (1990). Riboflavin requirement of chicks fed purified amino acid and conventional corn-soyabean diet. Poultry Sci.: 69: 1357-1365.

Dacie, J. W. and Lewis, S. .M (1977). Practical Haematology. Longman Group Ltd, Lond. Ed. 5. : 21-68.

Duncan, D.B. (1955). Multiple range test and F.test. Biometrics: 11:1-42

Fetuga, B. L. (1977). Efficient Utilization of feed resources and development of feeding technology suited for African region. Proc.WCAP.: 1: 113-121

National Research Council. (1994). Nutrient requirement of Poultry. National Academy Press. Washington DC. Ed. 9: 1- 15

Orji, B. and Okeke G. C. (1986). Haematological studies in guinea fowl (N. meleagris; pallas). Nig. J. of Anim. Prod. : 1986; 13:94-99

Sonaiya, E. B. (1986). Live and carcass performance of cockerels raised to 16 weeks on two caloric-protein diet. J.Anim.Prod. Res.: 6:73-79. 
Bolu and Ibikunle

Steel, R. G. D. and Torrie, J. H. (1980). Principles and procedures of statistics: A biometrical approach. New York, McGraw Hill Book Co. N.Y. Ed. 2: 27-54.

Yen, J. T. and Baker, D. H. (1977). Assessment of the availability of niacin in corn, soyabean and soyabean meal. J. Anim. Sci.: 45: 269-276. 